\title{
Saccharification of pretreated sawdust by Aspergillus niger cellulase
}

\author{
A. Sridevi · G. Narasimha · G. Ramanjaneyulu • \\ K. Dileepkumar · B. Rajasekhar Reddy • \\ P. Suvarnalatha Devi
}

Received: 28 December 2014/ Accepted: 21 February 2015/Published online: 19 March 2015

(C) The Author(s) 2015. This article is published with open access at Springerlink.com

\begin{abstract}
The efficiency of two methods of pretreatment ( $\mathrm{NaOH}$ and $\mathrm{H}_{2} \mathrm{O}_{2}$ ) on lignocelluloses-saw dust, wheat straw, sugarcane bagasse and rice bran-was compared in the present study. Alkali treatment of lignocelluloses relatively removed more hemicelluloses and lignin leaving behind cellulose content in the residues than peroxide treatment. Crude cellulase of Aspergillus niger, produced on the pretreated sawdust with highest cellulose content, was further tested for the release of soluble and reducing sugars during the saccharification process of same pretreated saw dust. The saccharification process of the pretreated sawdust with enzyme was optimized for $\mathrm{pH}$, temperature, and substrate concentration and proceeded optimally at $\mathrm{pH}$ of $5.0,50{ }^{\circ} \mathrm{C}$ and $0.5 \%$ pretreated sawdust. The rate of saccharification with crude enzyme of $A$. niger on alkali-treated sawdust was found to be maximum (23\%) as against $5.4 \%$ on native sawdust under optimal conditions after $48 \mathrm{~h}$. The present study indicates $\mathrm{NaOH}$ treated sawdust as a potential raw material for both production of cellulase and saccharification in a large scale.
\end{abstract}

Keywords Aspergillus niger - Lignocelluloses · Pretreatment $\cdot$ Sawdust $\cdot$ Cellulases

\footnotetext{
A. Sridevi · P. S. Devi

Department of Applied Microbiology, Sri Padmavathi Mahila University, Tirupati, AP, India

G. Narasimha

Department of Virology, Sri Venkateswara University, Tirupati, AP, India

A. Sridevi · G. Narasimha - G. Ramanjaneyulu •

K. Dileepkumar · B. R. Reddy ( $\square)$

Department of Microbiology, Sri Krishnadevaraya University,

Anantapuramu 515 003, AP, India

e-mail: rajasekharb64@gmail.com
}

\section{Introduction}

Lignocellulose is the major structural component of plant biomass such as woody and non-woody plants and represents major part of renewable organic matter and substrate available for conversion to fuels. On a worldwide basis, terrestrial plants produce $2.3 \times 10^{11}$ metric tons/year (dry weight basis) of wood, which is equivalent to $7 \times 10^{10}$ metric tons of coal or about two-thirds of the world's energy requirement. Available cellulosic feed stocks from agriculture and other sources are about 180 million tons/ year (Lynd et al. 2003). Furthermore, tremendous amounts of cellulose are available as municipal and industrial wastes which today contribute to our pollution problems. Thus, there is great interest in the use of cellulosic biomass as a renewable source of energy via breakdown to sugars that can then be converted to liquid fuel by cellulases.

Cellulase is a multi-enzyme complex involving the synergistic action of exo- $\beta-1,4$ glucanase (3.2.1.91), endo$\beta-1,4$ glucanase (3.2.1.4) and $\beta$-glucosidase (3.2.1.21). Cellulolytic enzymes can be produced upon growth of cellulolytic organisms on the cheap and best substrates like lignocelluloses. A variety of lignocellulosic substrates tried for industrial production of cellulase enzymes in submerged fermentation and solid state fermentation included sugarcane bagasse, wheat bran, rice bran, gram bran, wheat straw, rice straw, rice husk, soy-hull, sago hampas, grape vine, trimming saw dust, corn cobs, coconut, coir pith, banana waste, tea waste, cassava waste, palm oil mill waste, aspen pulp, sugar beet pulp, sweet sorghum pulp, apple pomace, peanut meal, rapeseed cake, coconut oil cake, mustard oil cake, cassava flour, wheat flour, corn flour, steamed rice and stream pretreated willow, depending on availability of substrates in different regions (Kumar et al. 2009; Zheng et al. 2014; Zheng and Rehmann 2014; Anwar 
et al. 2014). Sridevi et al. (2009) demonstrated high production of cellulase by a local isolate Aspergillus niger on commercial cellulose and natural lignocelluloses. Thus cellulase enzyme produced on cheap raw materials-lignocelluloses-in this fashion can be used for conversion of lignocelluloses into soluble sugars in a saccharification process which is a platform for potential development of technologies for production of fuels, chemicals, etc. However, use of natural lignocelluloses in enzymatic saccharification generated low yields of fermentable sugars because of less inaccessibility of cellulose component in lignocellulose to enzyme attack due to encasement of cellulose component in a matrix of lignin and hemicellulose.

Pretreatment is necessary to reduce recalcitrance of lignocellulosic biomass for enhancing cellulose component to enzymatic hydrolysis in subsequent steps. Even though a number of pretreatment methods have been tried individually or in combination to loosen structure of lignocellulosic biomass like milling, grinding, pyrolysis, highenergy radiation, alkaline or acid hydrolysis, gas treatment, hydrogen peroxide treatment, organic solvent treatment, wet oxidation and biological treatment, etc. (Kumar et al. 2009; Chaturvedi and Verma 2013; Muhammad Irfan et al. 2014; Marzieh Badiei et al. 2014; Langan et al. 2014), alkaline and acid pretreatment methods are popular (Iroba et al. 2013; Chen et al. 2013). Acid-pretreated methods were quite effective at only high temperature on different lignocellulosic biomasses with high recovery of cellulose compounds due to removal of hemicelluloses (Sun et al. 2014; Kapu and Trajano 2014). But, the most drawbacks with acid pretreatment methods were formation of inhibitor-furfural and hydroxyl methyl furfural which may affect fermentation in subsequent stages. Alkaline pretreatment methods facilitate removal of lignin component from lignocellulosic biomass leaving behind polysaccharide compound (Chen et al. 2013). In view of retaining of polysaccharide component in lignocellulosic biomass and operation of alkaline pretreatment method at low temperature (less energy process) and little information on influence of peroxide under alkaline conditions on structure of lignocellulosic biomass, the present study has been focussed on comparison of two methods-alkali method and alkaline peroxide method-for treatment of lignocellulose and understanding of enzymatic saccharification of pretreated lignocellulose.

\section{Materials and methods}

Production of cellulase

High cellulase enzyme production by a local fungal isolate of $A$. niger on the medium with following ingredients in $\mathrm{g} / \mathrm{L}: \quad \mathrm{NaNO}_{3}-1.0 ; \quad \mathrm{K}_{2} \mathrm{HPO}_{4}-1.0 ; \quad \mathrm{MgSO}_{4} \cdot 7 \mathrm{H}_{2} \mathrm{O}-0.5 ;$ $\mathrm{KCl}-0.5 ; \mathrm{FeSO}_{4} \cdot 7 \mathrm{H}_{2} \mathrm{O}-0.01$; pretreated sawdust-1.0 in a liter of distilled water with $\mathrm{pH}$ of 5.0 in submerged fermentation was demonstrated in our earlier study (Sridevi et al. 2009). The same medium was used for production of cellulase by the same local isolate of A. niger in the present study. Spores of A. niger (Narasimha et al. 1999) were produced on potato dextrose agar slants after 7 days of growth at $30{ }^{\circ} \mathrm{C}$. Three milliliters of spore suspension of $A$. niger with density of $2 \times 10^{8}$ spores $/ \mathrm{ml}$ was prepared from slants with sterile distilled water and was inoculated aseptically into enzyme production medium. The submerged culture was incubated at $30^{\circ} \mathrm{C}$ on a rotary shaker $(180 \mathrm{rpm})$ under axenic conditions. The filtrate, obtained after removal of mycelial mat by filtration through Whatman filter paper No.1 and followed by centrifugation at $10,000 \mathrm{~g}$ for $10 \mathrm{~min}$, was used as a crude enzyme source. Activity of different components in the crude enzyme source was measured in terms of Fpase, CMCase and $\beta-$ glucosidase.

Enzyme assays

\section{Filter paper assay}

Filter paper activity indicates total cellulolytic activity resulting from combined action of different enzyme components present in the culture filtrate. Filter paper activity of the culture filtrate of A. niger was determined according to the method of Mandels and Weber (1969). Whatman filter paper strips $(50 \mathrm{mg})$ in one $\mathrm{ml}$ of $0.05 \mathrm{M}$ sodium citrate buffer, $\mathrm{pH} 4.8$, at $50{ }^{\circ} \mathrm{C}$ with $1 \mathrm{ml}$ of enzyme source was incubated for $60 \mathrm{~min}$ at $50{ }^{\circ} \mathrm{C}$. The reducing sugars produced during incubation were determined by di-nitro salicylic acid (DNS) method (Miller 1959). Activity of cellulase was expressed in filter paper units (FPU). One unit of filter paper unit was defined as the amount of enzyme releasing $1 \mu \mathrm{mol} / \mathrm{min}$ of reducing sugar from filter paper.

\section{Carboxymethyl cellulase assay}

Activity of endoglucanase in the culture filtrate was determined by carboxymethyl cellulase method (Ghosh 1987). Assay of endoglucanase (Carboxymethyl cellulase) involved incubation of $1.0 \mathrm{ml}$ of $1 \%$ carboxymethyl cellulose (Merck) in $0.2 \mathrm{M}$ acetate buffer (pH 5.0) with $1 \mathrm{ml}$ of enzyme solution at $50{ }^{\circ} \mathrm{C}$ for one hour in a water bath. The reducing sugar formed in the reaction mixture was determined by di-nitro salicylic acid (DNS) method (Miller 1959). One unit of endoglucanase activity was defined as the amount of enzyme releasing $1 \mu \mathrm{mol} / \mathrm{min}$ of reducing sugar. 


\section{$\beta$-D-glucosidase assay}

Titre of $\beta$-glucosidase present in the culture filtrate was based on the method of Herr (1979). For the determination of $\beta$-D-glucosidase activity, the assay mixture with $0.2 \mathrm{ml}$ of $5 \mathrm{mM} \quad p$-nitrophenyl $\beta$-D-glucopyranoside (PNPG, Merck) in $0.05 \mathrm{M}$ citrate buffer $\mathrm{pH} 4.8$ and $0.2 \mathrm{ml}$ of culture filtrate was incubated for $30 \mathrm{~min}$ at $50{ }^{\circ} \mathrm{C}$ and the reaction was halted by adding $4 \mathrm{ml}$ of $0.05 \mathrm{M} \mathrm{NaOH}-\mathrm{g}-$ lycine buffer (pH-10.6). The yellow-coloured $p$-nitrophenol liberated was determined in a Spectrophotometer (ELICO-SL 164) at $420 \mathrm{~nm}$. One unit of $\beta$-glucosidase activity was defined as the amount of enzyme liberating $1 \mu \mathrm{mol} / \mathrm{min}$ of $p$-nitrophenol under standard assay conditions.

\section{Pretreatment of lignocelluloses}

Different lignocelluloses-saw dust, wheat straw, sugarcane bagasse and rice bran-were collected locally, chopped into $1-2 \mathrm{~cm}$ lengths and were treated separately by two pretreatment processes.

\section{Alkaline pretreatment}

Dried lignocellulose samples were incubated in $1 \mathrm{~N} \mathrm{NaOH}$ solution at the rate of $50 \mathrm{ml} / \mathrm{g}$ at room temperature for $24 \mathrm{~h}$ following which the slurries were washed repeatedly with water to a neutral $\mathrm{pH}$, and then oven dried at $60{ }^{\circ} \mathrm{C}$ to a constant weight.

\section{Oxidative pretreatment}

Samples (one gram) of lignocellulose of each type were placed in $50 \mathrm{ml}$ of distilled water containing $1 \% \mathrm{H}_{2} \mathrm{O}_{2}$ (W/ $\mathrm{V}$ aqueous solution). The suspension was adjusted to $\mathrm{pH}$ 11.5 with $\mathrm{NaOH}$ and stirred gently at room temperature $\left(25^{\circ} \mathrm{C}\right)$ for $20 \mathrm{~h}$. The insoluble residue was collected by filtration, washed with distilled water until neutrality and dried at $110{ }^{\circ} \mathrm{C}$ overnight (Gould 1984). The oven-dried materials were packed in polythene bags and stored under dry conditions at room temperature until use.

\section{Gravimetric analysis}

The different components present in lignocelluloses used in this study were determined by sequential chemical extraction according to the method of Harper and Lynch (1981). One gram sample of each pretreated lignocellulose and native lignocellulose (untreated sample dried at $60{ }^{\circ} \mathrm{C}$ for $16 \mathrm{~h}$ ) were weighed into $125 \mathrm{ml}$ conical flasks.

For the determination of hot water-soluble fraction, $75 \mathrm{ml}$ of distilled water was added to $1 \mathrm{~g}$ of native and pretreated lignocelluloses and boiled gently for $1 \mathrm{~h}$. The water was changed and the mixture was boiled again for $1 \mathrm{~h}$. The residue was recovered and washed with cold water and dried at $60{ }^{\circ} \mathrm{C}$ for overnight and carefully weighed. Loss in weight of residue after hot water treatment was hot water-soluble fraction.

To determine hot ethanol soluble fraction, $100 \mathrm{ml}$ of ethanol was added to the solid sample obtained at the end of the previous treatment and boiled for $2 \mathrm{~h}$. The residue obtained from each lignocellulose was washed twice with ethanol and twice with water, dried at $60^{\circ} \mathrm{C}$. Weight difference in solid residue recovered at the end of water process and at the end of ethanol process was hot ethanol fraction.

To find out the lignin content in all lignocellulosic samples with/without treatment used in this study, $30 \mathrm{ml}$ of water, $2 \mathrm{ml}$ of $10 \%(\mathrm{v} / \mathrm{v})$ aqueous acetic acid solution and $0.6 \mathrm{~g}$ of sodium hypochlorite were added to the residues obtained at the end of hot ethanol process. The mixture was heated at $70{ }^{\circ} \mathrm{C}$ for $1 \mathrm{~h}$ and then $2 \mathrm{ml}$ of acid and $0.6 \mathrm{~g}$ of sodium hypochlorite were added again. After $2 \mathrm{~h}$ of treatment, the residues were washed five times with water, twice with acetone and once with ether, dried then at $105{ }^{\circ} \mathrm{C}$ for $90 \mathrm{~min}$ and weighed. The weight difference between residue recovered after ethanol treatment and residue recovered after the present treatment gives the lignin content.

To measure the hemicellulose content, $20 \mathrm{ml}$ of $24 \%$ $\mathrm{KOH}$ solution was added to the solid residue recovered after the determination of lignin content and left then to stand for $2 \mathrm{~h}$ at $20^{\circ} \mathrm{C}$. The residues were then washed five times with water followed by one washing with $5 \%$ aqueous acetic acid solution, one washing of water, one washing of acetone and one washing of ether. Finally, the samples were dried at $60{ }^{\circ} \mathrm{C}$ for $90 \mathrm{~min}$ and weighed. The weight difference gives the hemicellulose content. The weight of the remaining residue after removal of lignin and hemicellulose was taken as the cellulose content.

Enzymatic sachaarification of native and alkali treated sawdust

Only the lignocellulose-sawdust with high cellulosewas used for the study of saccharification. Sample of $2.5 \mathrm{~g}$ (W/V) each from native and alkali-treated substrate was placed in $50 \mathrm{ml}$ of $0.05 \mathrm{M}$ citrate buffer in $250 \mathrm{ml}$ stoppered conical flasks. Prior to addition of the enzyme preparation to the native and pretreated sawdust samples, the substrate and buffer mixture were autoclaved for $20 \mathrm{~min}$ at $121^{\circ} \mathrm{C}$ to prevent contamination. Three milliliters of A. niger crude culture filtrate (FPU-6.3 U/ml, CMCase-7.2 U/ml, $\beta$-Glucosidase- $0.30 \mathrm{U} / \mathrm{ml}$ ) were added to the above flasks and incubated at $180 \mathrm{rpm}$ at $50{ }^{\circ} \mathrm{C}$ with pH of 5.0 for $72 \mathrm{~h}$. Flasks in which no enzyme 
was added served as control. Samples from each set were taken after 24, 48 and $72 \mathrm{~h}$. The reaction was stopped by keeping tubes on ice cold water bath and the contents of the tubes were centrifuged for $10 \mathrm{~min}$ at $4{ }^{\circ} \mathrm{C}$. The reducing sugar content in the supernatant was measured by DNS method (Miller 1959). The percent hydrolysis was calculated using the following equation:

Percent of hydrolysis

$$
=\frac{\text { Total sugars }(\mathrm{g}) \times 0.9 \times 100}{\text { Weight of alkali }- \text { treated saw dust }(\mathrm{g}) / \text { untreated saw dust }}
$$

In order to find out influence of temperature on saccharification process, another set of flasks with the same reaction mixture were incubated at different temperatures-30, 40.50 and $60{ }^{\circ} \mathrm{C}$. In another experiment, saccharification was carried out with incubation of the same reaction mixture in the medium buffered with $0.05 \mathrm{M}$ citrate buffer adjusted to different $\mathrm{pH}-4.5,5.0,5.5$ and 6.0. In another experiment, to study the influence of substrate concentration on enzymatic hydrolysis, four different concentrations of both native and treated sawdust $(0.5,1.0,2.5$ and $5.0 \%)$ were included in $50 \mathrm{ml}$ of $0.05 \mathrm{M}$ citrate buffer and incubated after addition of crude enzyme at $\mathrm{pH} 5.0$ and $50{ }^{\circ} \mathrm{C}$ with suitable controls. In all these experiments, the reaction was arrested and flasks were processed in the same fashion as mentioned earlier.

\section{Statistical analysis}

All experiments were performed in triplicate and the related data were expressed as mean \pm standard deviation. The experimental data from enzymatic saccharification were statistically analysed using SPSS program by oneway analysis of variance (ANOVA) followed by Duncan's multiple range method test to separate the means.
Differences in means were judged significant when $p$ values for the null hypothesis were 0.05 or less (Estrada et al. 1988).

\section{Results and discussion}

Analysis of composition of lignocellulosic masses used in the present study indicated that the native and untreated lignocelluloses - sawdust, sugarcane bagasse, wheat straw and rice bran-contained cellulose component to the extent of $47.7,43.7,43.9$ and $45.7 \%$, respectively (Table 1). Hemicellulose is the second dominant component (16.9, $15.8,15.0$ and $14.0 \%$ ) in the same four native lignocelluloses, while lignin constituted 12.4, 12, 10.9 and $11.8 \%$ of total dry weight of raw lignocelluloses, respectively (Table 1). Results of the present study on composition of hardwood such as saw dust and rice straw in terms of cellulose, hemicellulose and lignin were comparable to the results of other studies on composition of the same lignocellulosic masses reported earlier (Hu 2006; Shulga et al. 2007; Song et al. 2012; Amiri et al. 2014). However, cellulose content of wheat straw and sugarcane bagasse in the present study was on the higher side in comparison to other studies (da Silva et al. 2010; Rabelo et al. 2011; Yang et al. 2011a, b; Wang et al. 2014; Hui et al. 2014). Variation in composition of lignocellulosic masses in different studies may be attributed to different agronomic and cultural practices adopted for growth of the plants and different methods employed for analysis of composition. Two pretreatment methods-alkali method and alkaline peroxide method-were performed on four lignocelluloses such as sawdust, sugarcane bagasse, wheat straw and rice bran at low (ambient) temperature in this study. Alkali treatment with $\mathrm{NaOH}$ at room temperature resulted in a considerable removal of different components, resulting in an increase in cellulose content from 47.7 to $63.1 \%$ in pretreated

\begin{tabular}{|c|c|c|c|c|c|c|c|c|c|c|c|c|}
\hline \multirow[t]{3}{*}{ Fraction } & \multicolumn{12}{|c|}{ Percentage of dry weight of fractions in } \\
\hline & \multicolumn{4}{|l|}{ Native } & \multicolumn{4}{|c|}{$\mathrm{NaOH}$-treated } & \multicolumn{4}{|c|}{$\mathrm{H}_{2} \mathrm{O}_{2}$-treated } \\
\hline & Sawdust & $\begin{array}{l}\text { Wheat } \\
\text { straw }\end{array}$ & $\begin{array}{l}\text { Sugarcane } \\
\text { bagasse }\end{array}$ & $\begin{array}{l}\text { Rice } \\
\text { bran }\end{array}$ & Sawdust & $\begin{array}{l}\text { Wheat } \\
\text { straw }\end{array}$ & $\begin{array}{l}\text { Sugarcane } \\
\text { bagasse }\end{array}$ & $\begin{array}{l}\text { Rice } \\
\text { bran }\end{array}$ & Sawdust & $\begin{array}{l}\text { Wheat } \\
\text { straw }\end{array}$ & $\begin{array}{l}\text { Sugarcane } \\
\text { bagasse }\end{array}$ & $\begin{array}{l}\text { Rice } \\
\text { bran }\end{array}$ \\
\hline $\begin{array}{l}\text { Hot water-soluble } \\
\text { fraction }\end{array}$ & 16.1 & 17.9 & 17.9 & 19.6 & 3.7 & 8.9 & 9.7 & 10.7 & 15.2 & 12.7 & 15.8 & 17.5 \\
\hline $\begin{array}{l}\text { Hot ethanol- } \\
\text { soluble fraction }\end{array}$ & 6.9 & 10.7 & 11.1 & 9.8 & 2.8 & 6.7 & 7.1 & 11.4 & 10.1 & 9.3 & 7.9 & 8.6 \\
\hline Lignin & 12.4 & 11.9 & 12.1 & 10.9 & 10.9 & 10.2 & 11.2 & 10.2 & 6.8 & 6.9 & 9.7 & 7.9 \\
\hline Hemicellulose & 16.9 & 15.80 & 15.0 & 14.0 & 19.5 & 16.9 & 15.9 & 14.1 & 17.9 & 16.1 & 15.0 & 13.5 \\
\hline Cellulose & 47.7 & 43.7 & 43.9 & 45.7 & 63.1 & 57.3 & 56.1 & 53.6 & 50.0 & 55.0 & 51.6 & 52.5 \\
\hline
\end{tabular}

Table 1 Chemical composition of native and pretreated lignocelluloses

Values in the table are means of results of three experiments 
sawdust, 43.7-57.3\% in wheat straw, 43.9-56.1\% in sugarcane bagasse and 45.7-53.6\% in case of rice bran (Table 1). The treatment of alkaline hydrogen peroxide increased cellulose content from 47.7 to $50 \%$ in sawdust, $43.7-55.0 \%$ in wheat straw, 43.9-51.6\% in sugarcane bagasse and 45.7-52.5\% in rice bran. Lignocelluloses treated by both methods were referred to as partially delignified lignocelluloses. Alkali-treated sawdust had retained more cellulose than other lignocelluloses in the present study. Use of $2.4 \% \mathrm{NaOH}$ at lower temperature $-80{ }^{\circ} \mathrm{C}$ for 70 min caused maximum removal of $43 \%$ of lignin (Uzunlu et al. 2014) in poppy stalks. The results thus obtained in the present study are in agreement with Thakur et al. (2013) who also reported dilute $\mathrm{NaOH}$ pretreatment as an effective method. Similarly, pretreatment of substrates with alkali may result in the swelling of the particle causing easy lignin removal and cellulose depolymerization (Damisa et al. 2008). But final content of cellulose in lignocelluloses after treatment with oxidative treatment was lower than that yielded from lignocelluloses after treatment with alkali method. With increasing concentration of $\mathrm{H}_{2} \mathrm{O}_{2}$ up to $5 \%$ under alkaline conditions, greater destruction of all cell wall components in lignocelluloses with concomitant decline in cellulose content and weight loss was observed (Irfan et al. 2011). Similarly, rather higher oxidation of cellulose component in comparison to other components in lignocellulose could be a reason for low recovery of cellulose with alkaline peroxide method in the present study. On the other hand, increasing the amount of alkaline hydrogen peroxide up to $4.3 \%$ in the pretreatment resulted in progressive reduction of lignin with concomitant increase of cellulose in cashew apple bagasse $(\mathrm{CAB})$ and lignin was reduced from original composition of 36-7 \% in the pretreated solid residue (Correia et al. 2013). Among five different pretreatment methods employed on sweet sorghum bagasse (Cao et al. 2012), the method of dilute $\mathrm{NaOH}(2 \%)$ autoclaving and $\mathrm{H}_{2} \mathrm{O}_{2}$ immersion caused removal of concentration of $91 \%$ of lignin along with the $34 \%$ of hemicellulose but retained cellulose with minimal loss.

\section{Optimization of saccharification of sawdust}

Experiments on saccharification in enzymatic digestion were conducted only on sawdust because of its high cellulose component. Yields of sugars in saccharification process upon incubation of alkali-treated and native sawdust with crude cellulase enzyme at loading of $7.56 \mathrm{FPU} / \mathrm{g}$, $8.60 \mathrm{U} / \mathrm{g}$ of CMCase and $0.36 \mathrm{U} / \mathrm{g} \beta$-glucosidase were compared (Fig. 1). Incubation of both treated and native sawdust with crude cellulase of $A$. niger resulted in release of soluble sugars in saccharification process. Higher saccharification efficiency (14\%) was recorded with alkali-

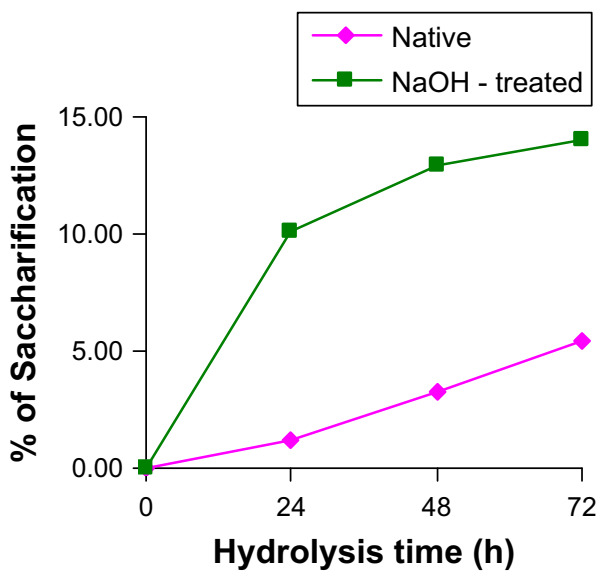

Fig. 1 Saccharification of native and $\mathrm{NaOH}$-treated sawdust by crude cellulase of Aspergillus niger

treated saw dust as against $5.4 \%$ with native sawdust. About threefold increase in hydrolysis of treated sawdust was observed in comparison to untreated sawdust. Similarly, about $47 \%$ more glucose yields were obtained from enzymatic (25 FPU/g, $40 \mathrm{IU} \beta$-glucosidase/g) hydrolysis of $5 \%$ rice straw pretreated with organosolve method in comparison to yields from untreated rice straw (Amiri et al. 2014). Incubation of crude cellulolytic-ligninolytic enzymatic extracts of Pleurotus ostreatus and $P$. chrysosporium with banana waste after sequential pretreatment with $3 \% \mathrm{HCl}$ first and then $3 \% \mathrm{NaOH}$ released reducing sugars up to $63.65 \mathrm{gL}^{-1}$ (Xenia et al. 2011). In a majority of studies, cellulase enzyme of commercial grade was used at rate of loading higher than that used in the present study. For instance, saccharification of pretreated rice straw with $50 \mathrm{FPU}$ of cellulase and $10 \mathrm{U}$ of $\beta$-glucosidase gave yields $(26.3 \mathrm{~g} / \mathrm{L})$ of reducing sugars higher than that $(17.79 \mathrm{~g} / \mathrm{L})$ of pretreated sugar cane bagasse with the same enzyme load (Sukumaran et al. 2009). Pretreated rice straw (Remli et al. 2014) and pretreated wheat straw (Feng et al. 2014) were digested with cellulase at loading of 10-15 FPU/g with/without $\beta$-glucosidase. Saccharification of feedstocks with/without pretreatment was carried out with cellulase at loading rate of 30-60 FPU/g for solubilisation of sugars (Thomsen et al. 2012; Wang 2014; Zhang et al. 2012). Recovery of glucose increased with increase in dosage of cellulase from $5 \mathrm{U}$ to $10 \mathrm{U} / \mathrm{g}$ along with $20 \mathrm{U}$ of $\beta$-glucosidase (Li et al. 2014).

\section{Effect of temperature}

In order to increase the sugar production during the saccharification of pretreated sawdust, the main experimental variables $-\mathrm{pH}$, temperature and substrate concentrationwere further optimized in our final experiments. Saccharification of sawdust when carried out at $50{ }^{\circ} \mathrm{C}$ 

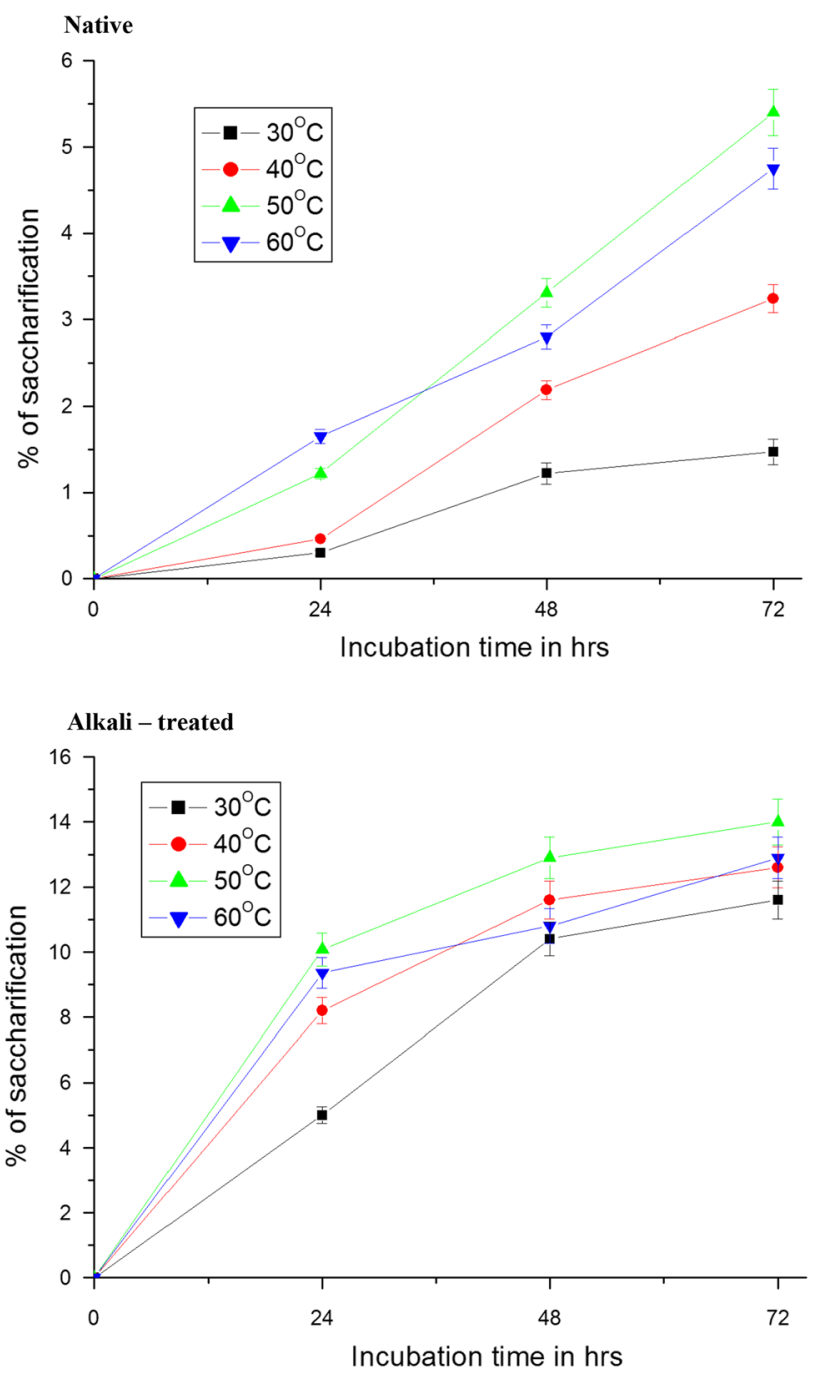

Fig. 2 Effect of temperature on enzymatic hydrolysis of native and $\mathrm{NaOH}$-treated sawdust by crude cellulase of Aspergillus niger

temperature caused maximum release of sugars (Fig. 2). After $72 \mathrm{~h}$ of incubation, approximately 5.4 and $14 \%$ of substrate were hydrolysed at $50{ }^{\circ} \mathrm{C}$ temperature from native sawdust and treated sawdust, respectively. Temperatures above or below optimal temperature caused a significant decrease in the hydrolysis rate. These results clearly show that the optimal temperature for hydrolysis of native and alkali-treated sawdust was $50{ }^{\circ} \mathrm{C}$. When the saccharification process of lignocelluloses proceeds at low temperature it would be desirable for industrial application because of less input of energy. The rate of hydrolysis was increased with increase in incubation time probably due to the attack of enzymes on amorphous regions in the initial stages (Desai et al. 1997). As the reaction proceeded and the amorphous regions were exhausted, the overall rate of hydrolysis rate slowed down due to slow attack of enzyme on crystalline regions. In addition to crystallinity, perhaps reactive cellulose chain ends were made during pretreatments and were hydrolysed by cellobiohydrolases much faster than the endoglucanase enzymes could replace them in the initial stages of hydrolysis (Converse 1993). In the same way, the optimum temperature for saccharification was found to be $50{ }^{\circ} \mathrm{C}$ in studies of Ortega et al. (2000). Crude extract of A. niger hydrolysed $80.3 \%$ of alkali-treated wheat straw, the ammonium sulphate precipitated enzyme hydrolysed $79.1 \%$ of substrate while dried moldy substrate caused $82.8 \%$ hydrolysis at $50{ }^{\circ} \mathrm{C}$ after $48 \mathrm{~h}$ (Fadel 2000). Rice straw with/without pretreatment was subjected to enzymatic hydrolysis at $45^{\circ} \mathrm{C}$ (Amiri et al. 2014). A maximum of $440 \mathrm{mg}$ glucose/g dry biomass was obtained in enzymatic saccharification from Erica spp. pretreated at $180{ }^{\circ} \mathrm{C}$ with $2.75 \%$ of sulfuric acid for $75 \mathrm{~min}$ in the presence of $0.25 \mathrm{~g} / \mathrm{g}$ dry biomass of PEG 4000 (Gil et al. 2010).

\section{Effect of $\mathrm{pH}$}

Hydrolysis of alkali - treated sawdust with crude cellulase of A. niger at different $\mathrm{pH}$ was carried out and hydrolysis rates were measured. Figure 3 explains the influence of $\mathrm{pH}$ on saccharification of treated sawdust. Hydrolysis of treated sawdust after $72 \mathrm{~h}$ occurred at the maximal rate of $14 \%$ at pH 5.0. Hydrolysis of sawdust at other pHs, 4.5, 5.5 and 6.0, was lower side in comparison to that of $\mathrm{pH}$ 5.0. Thus it is evident from these results that $\mathrm{pH} 5.0$ was optimal for achieving maximum hydrolysis of sawdust with cellulase of A. niger Similarly, the optimum $\mathrm{pH}$ for saccharification of treated wheat straw was found to be 5.0 according to studies of Ortega et al. (2000). Crude extract of A. niger hydrolysed $80.3 \%$ of alkali-treated wheat straw at pH 4.5 (Fadel 2000). The degradation of cell wall structure materials by cellulases derived from different organisms at different $\mathrm{pH}$ and temperature proceeded at different rates because the susceptibility of cellulosic substrates to enzymatic hydrolysis was dependent on a number of factors including structural features related to cellulose crystallinity (Fan et al. 1991; Mads et al. 2011), degree of polymerization (Sinitsyn et al. 1991), lignin content (Gharpuray et al. 1983) or surface area exposed to cellulases (Thompson et al. 1992).

\section{Effect of substrate concentration}

Enzymatic hydrolysis of pretreated sawdust as function of substrate concentration is shown in Fig. 4. Saccharification on the pretreated sawdust at the lowest $0.5 \%$ concentration occurred at maximal rate in $48 \mathrm{~h}$, whereas saccharification on the native sawdust at the same concentration proceeded slowly. Twenty-three per cent of hydrolysis took place on treated sawdust as against $4 \%$ on the native sawdust during $48 \mathrm{~h}$. Increasing the sawdust concentration from 0.5 to $5 \%$ decreased the saccharification rate. It is clear from 

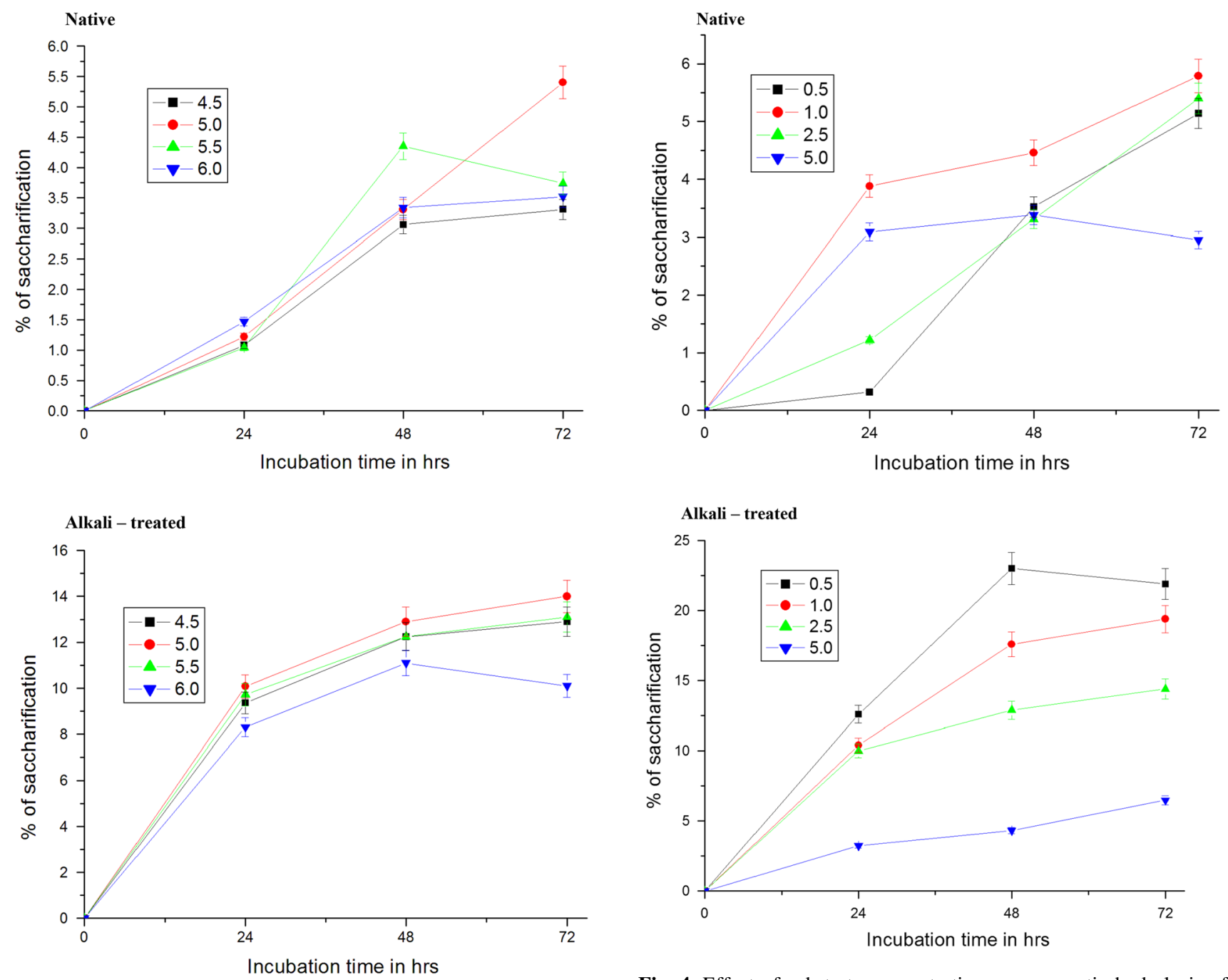

Fig. 3 Effect of $\mathrm{pH}$ on enzymatic hydrolysis of native and $\mathrm{NaOH}-$ treated sawdust by crude cellulase of Aspergillus niger

Fig. 4 Effect of substrate concentration on enzymatic hydrolysis of native and $\mathrm{NaOH}$-treated sawdust by crude cellulase of Aspergillus niger

the results of the present study that the pretreated sawdust at $0.5 \%$ concentration was optimal for enzymatic hydrolysis with maximum yield of fermentable sugars at enzyme load used in the present study. Results on hydrolysis of alkali-treated sawdust after $48 \mathrm{~h}$ by $T$. reese $i$ cellulase and A. niger $\beta$-glucosidase (Desai et al. 1997) were in agreement with these results of the present study. No improvement in yields of glucose in enzymatic hydrolysis with increase in loading of rice straw from 5 to $8 \%$ (Amiri et al. 2014) was also in conformity with the results of the present study. The rate (6-14\%) of enzymatic saccharification of pretreated lignocellulose with locally produced cellulase (crude) was lower than the rate (33-63\%) of saccharification of same lignocellulose with commercial cellulase enzyme under similar conditions (Irfan et al. 2011). Concentration of cellulase enzyme used in this study for saccharification may not be adequate to support saccharification of pretreated sawdust at higher

concentrations, but needs to be tested at different higher loading of cellulose enzyme. The association of cellulose with lignin and hemicellulose in the lignocellulosic materials is an important factor limiting the susceptibility to hydrolysis (Yang et al. 2011a). Higher rate of saccharification of pretreated sawdust with crude cellulase in the present study could be due to enhancement in the accessibility of cellulase to cellulose because of opening of cell wall structure with removal of the matrix. Loading of crude/pure cellulase in supplementation with high $\beta$-glucosidase at high concentrations may further improve the yields of the saccharification. For each pair, the mean difference, its standard deviation and the results of the $t$ test were studied (Table 2). Basing on the $p$ value of the $t$ test, the differences in all pairs are significant. In all the conditions (Temp, $\mathrm{pH}$, Substrate Conc.), the amount of glucose liberated was significantly different between native and alkali treated sawdust.

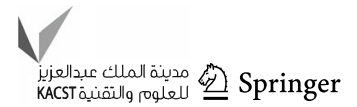




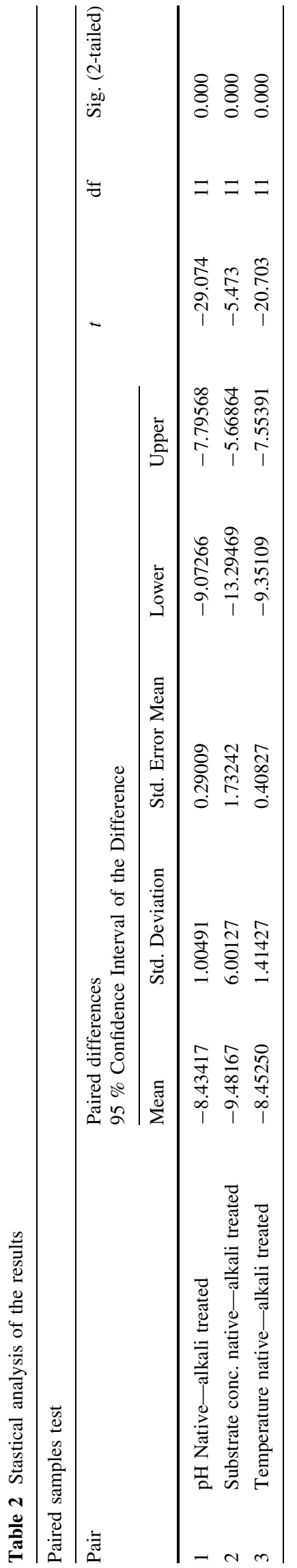

\section{Conclusions}

As cellulose is encased in a matrix of lignin and hemicellulose in lignocelluloses, cellulose component is less inaccessible to enzyme hydrolysis. Of the two pretreatment methods-alkaline $(\mathrm{NaOH})$ and peroxide $\left(\mathrm{H}_{2} \mathrm{O}_{2}\right.$ - treatment), tested on lignocelluloses, alkaline treatment had retained more cellulose component in all four lignocelluloses used in this study. Enzymatic saccharification of alkali-treated sawdust with highest cellulose content released higher yields of soluble sugars in comparison to native sawdust. Parameters- $\mathrm{pH}$, temperature and substrate concentration affecting hydrolysis of sawdust-were optimized for increasing the rate of saccharification process. Hydrolysis of $\mathrm{NaOH}$-treated sawdust with crude cellulase of A. niger yielded reducing sugars of $23 \%$ under optimal conditions of $0.5 \%$ substrate concentration, $\mathrm{pH} 5.0$ and $50{ }^{\circ} \mathrm{C}$ temperature in $48 \mathrm{~h}$ in comparison to $4 \%$ from native sawdust. It is clear from this study that pretreated lignocellulosic substrates can be tapped as a source for the production of fermentative sugars that can be subsequently used for different value addition products.

Acknowledgments We acknowledge the financial assistance provided by the University Grants Commission, New Delhi, in the form of fellowships to A. Sridevi, G. Ramanjaneyulu and K. Dileep Kumar to carry out the above research.

Open Access This article is distributed under the terms of the Creative Commons Attribution License which permits any use, distribution, and reproduction in any medium, provided the original author(s) and the source are credited.

\section{References}

Amiri H, Karimi K, Zilouei H (2014) Organosolv pretreatment of rice straw for efficient acetone, butanol, and ethanol production. Biores Tech 152:450-456

Anwar Z, Gulfraz M, Irshad M (2014) Agro-industrial lignocellulosic biomass a key to unlock the future bio-energy: a brief review. J Radiat Res Appl Sci 7(2):163-173

Badiei M, Asim N, Jahim JM, Sopian K (2014) Comparison of chemical pretreatment methods for cellulosic biomass. APCBEE Proced 9:170-174

Cao W, Sun C, Liu R, Yin R, Wu X (2012) Comparison of the effects of five pretreatment methods on enhancing the enzymatic digestibility and ethanol production from sweet sorghum bagasse. Bioresour Technol 111:215-221

Chen Y, Stevens MA, Zhu Y, Holmes J, Xu H (2013) Understanding of alkaline pretreatment parameters for corn stover enzymatic Saccharification. Biotechnol Biofuels 6(8):1-10

Chaturvedi V, Verma P (2013) An overview of key pretreatment processes employed for bioconversion of lignocellulosic biomass into biofuels and value added products. Biotech 3(5):415-431

Converse AO (1993) Substrate factors limiting enzymatic hydrolysis. In: Saddler (ed) Bioconversion of Forest and Agricultural plant residue. C.A.B.Intl, Wallingford, pp 93-416 
Correia JA, Júnior JE, Gonc LRB, Alves LR, Rocha MV (2013) Alkaline hydrogen peroxide pretreatment of cashew apple bagasse for ethanol production: study of parameters. Bioresour Technol 139:249-256

Da Silva ASA, Inoue H, Enob T, Yano S, Bon EPS (2010) Milling pretreatment of sugarcane bagasse and straw for enzymatic hydrolysis and ethanol fermentation. Bioresour Technol 101(19):7402-7409

Damisa DI, Ameh JB, Umoh VJ (2008) Effect of chemical pretreatment of some lignocellulosic wastes on the recovery of cellulase from Aspergillus nigerAH3 mutant. Afr J Biotechnol 7:2444-2450

Desai SG, Converse AO (1997) Substrate reactivity as a function of the extent of reaction in the enzymatic hydrolysis of lignocelluloses. Biotech Bioeng 50:650-655

Estrada P, Acebal C, Castillan MP, Mata A, Romero A (1988) Adsorption of cellulose from Trichoderma ressei on wheat straw. Biotech Appl Biochem 10:49-58

Fadel M (2000) Production physiology of cellulases and $\beta$-glucosidase enzymes of Aspergillus niger grown under solid state fermentation conditions. J Bio sci. 1:401-411

Fan LT, Lee YH, Beardmore DH (1991) The influence of major structural features of cellulose on rate of enzymatic hydrolysis. Biotechnol Bioeng 23:419-424

Feng L, Qin L, Liu Z-H, Dong C-Y, Li B-Z, Yaun Y-J (2014) Combined severity during pretreatment chemical and temperature on the saccharification of wheat straw using acid and alkali of different strength. Bioresources 9(1):24-38

Gharpuray MM, Lee YH, Fan LT (1983) Structural modification of lignocelluloses by pretreatment to enhance enzymatic hydrolysis. Biotechnol Bioeng 23:157-172

Ghosh TK (1987) Measurement of cellulase activities. Pure Appl Chem 59:257-268

Gil N, Ferreira S, Amaral ME, Domingues FC, Duarte AP (2010) The influence of dilute acid pretreatment conditions on the enzymatic saccharification of Erica spp. for bioethanol production. Ind Crops Prod 32:29-35

Gould SM (1984) Alkaline peroxide delignification of agricultural residues to enhance enzymatic saccharification. Biotechnol Bioeng 23:157-172

Harper SHT, Lynch SM (1981) The chemical components and decomposition of wheat straws leaves internodes and nodes. J Sci Food Agri 323:1057-1062

Herr LJ (1979) Secretion of cellulases and $\beta$-glucosides by Trichoderma viridae TTCC 1433 in submerged cultures on different substrates. Biotechnol Bioeng 21:1361-1363

Hu Z, Yeh T-F, Chang H, Matsumoto Y, Kadla JF (2006) Elucidation of the structure of cellulolytic enzyme lignin. Holzforschung 60(4):389-397

Hui L, Huangwei X, Kunlun D (2014) Optimum bioconvertion of glucose: ethanol pretreatment. Bioresources 9(2):3163-3173

Irfan M, Gulsher M, Abbas S, Syed Q, Nadeem M, Baig S (2011) Effect of various pretreatment conditions on enzymatic saccharification. Songklanakarin J Sci Technol 33(4):397-404

Irfan M, Nadeem M, Syed Q (2014) Ethanol production from agricultural wastes using Sacchromyces cervisae Braz. J Microbiol 45(2):457-465

Iroba KL, Tabil LG, Dumonceaux T, Baik O (2013) Effect of alkaline pretreatment on chemical composition of lignocellulosic biomass using radio frequency heating. Biosyst Eng 116(4):385-398

Kapu NS, Trajano HL (2014) Review of hemicellulose hydrolysis in softwoods and bamboo. Biofpr 8(6):857-870

Kumar P, Barrett DM, Delwiche MJ, Stove P (2009) Methods for pretreatment of lignocellulosic biomass for efficient hydrolysis and biofuel production. Ind Chem. Res, Eng. doi:10.1021/ ie801542g
Langan P, Petridis L, O'Neill HM, Pingali SV, Foston M, Nishiyama YS, Schulz Y, Lindner R, Hanson B, Harton BL, Heller S, Urban WT, Evans V, Gnanakaran BR, Ragauskas S, Smith AJ, Davison JC, Brian H (2014) Common processes drive the thermochemical pretreatment of lignocellulosic biomass. Green Chem 16:63-68

Li Z, Li W-Z, Hanping H, Shuai Z, Wang Z, Jameel H, Chang H-M (2014) Pretreatment of corn stover for sugar production by a two-step process using dilute hydrochloric acid followed by awueous ammonia. Bioresources. 9(3):4622-4635

Lynd LR, Jin H, Michels JG, Wyman CE, Dale B (2003) Bioenergy: background, potential, and policy. Center for Strategic and International Studies, Washington, D.C.

Mads P, Johansen KS, Meyer AS (2011) Low temperature lignocellulose pretreatment: effects and interactions of pretreatment $\mathrm{pH}$ are critical for maximizing enzymatic monosaccharide yields from wheat straw. Biotech Biofuel 4(11):2-10

Mandels M, Weber J (1969) In: (ed) Cellulases and its application. Advances in Chemistry Series. American Chemical Society, Washington DC, pp 391-414

Miller GL (1959) Use of dinitrosalicylic acid reagent for determination of reducing sugars. Anal Chem 31:426-429

Narasimha G, Babu GVAK, Rajasekhar Reddy B (1999) Cellulolytic activity of fungal cultures isolated from soil contaminated with effluents of cotton ginning industry. J Env Biol 20:235-239

Ortega N, Busto MD, Mateos MP (2000) Enzymatic saccharification of pretreated wheat straw by T.reesei cellulases and A.niger $\beta$ glucosidase. Biocatal Biotrans 18:311-330

Rabelo SC, Amezquita Fonseca NA, Andrade RR, Maciel Filho R, Costa AC (2011) Ethanol production from enzymatic hydrolysis of sugarcane bagasse pretreated with lime and alkaline hydrogen peroxide. Biomass Bioenergy 35(7):2600-2607

Remli NAM, Shah UKM, Mohamad R, Abd-Aziz S (2014) Effect of chemical and thermal pretreatments on the enzymatic saccharification of rice straw for sugar production. Bioresources 9(1):510-522

Shulga G, Betkers T, Shakels V, Neiberte B, Verovkins A, Brovkina J, Belous O, Ambrazaitene D, Zukauskaite A (2007) Effect of the modification of lignocellulosic materials with a ligninpolymer complex on their mulching properties. BioResources 2(4):572-582

Sinitsyn AP, Gusakov AV, Vuasenbko EY (1991) Effect of structural and physicochemical features of cellulosic substrates on the efficiency of enzymatic hydrolysis. App Biochem Biotechnol. 30:43-59

Song Z, Yang G, Guo Y, Zhang T (2012) Comparision of two chemical pretreatments of rice straw for biogas production by anaerobic digestion. Bioresources 7(3):3223-3236

Sridevi A, Narasimha G, Rajasekhar Reddy B (2009) Production of Cellulase by Aspergillus niger on natural and pretreated lignocellulosic wastes. Internet J Microbiol 7:580-592

Sukumaran RK, Singhania RR, Mathew G M, Pandey A (2009) Cellulase production using biomass feed stock and its application in lignocellulose saccharification for bio-ethanol production. Renew Energy 34:421-424

Sun Q, Foston M, Meng X, Sawada D, Pingali S, Hugh M, O’Neill HL, Charles E, Wyman PL, Art J, K R, Kumar R (2014) Effect of lignin content on changes occurring in poplar cellulose ultrastructure during dilute acid pretreatment. Biotech Biofuels 7:150

Thakur S, Bhuvnesh S, Snehal I, Kuhad RC, Akshaya G (2013) Degradation and selective ligninolysis of wheat straw and banana stem for an efficient bioethanol production using fungal and chemical pretreatment. 3. Biotech 3:365-372

Thompson DN, Chen HC, Grethlein HC (1992) Comparison of pretreatment methods on the basis of available surface area. Biores Technol 39:155-163

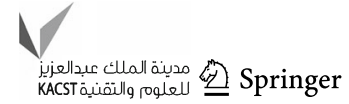


Thomsen ST, Jensen M, Schmidt JE (2012) Production of 2nd generation bioethanol from Lucerne-optomization of hydrothermal pretreatment. Bioresources 7(2):1582-1593

Uzunlu N, Hosgun EZ, Bozan B (2014) Optimization of alkaline pretreatment for enzymatic saccharification of poppy stalks. Bioresources 9(2):2824-2834

Wang W, Yuan T, Cui B (2014) Biological pretreatment with White rot fungi and their Co-Culture to overcome lignocellulosic recalcitrance for improved enzymatic digestion. BioResources 9(3):3968-3976

Xenia M-E, Barahona-Pérez F, Alzate-Gaviria L, Rodríguez-Vázquez R, Simá MT, Domínguez-Maldonado J, Canto-anché BB (2011) Saccharification with Phanerochaete chrysosporium and pleurotus ostreatus enzymatic extracts of pretreated banana waste. Afr J Biotechnol 10:3824-3834
Yang B, Dai Z, Ding S-Y, Wyman CE (2011a) Enzymatic hydrolysis of cellulosic biomass. Biofuels 2(4):421-450

Yang J, Wang G, Qi L, Xu J (2011b) Optimizing sulphate pretreatment for saccharification of wheat straw using orthogonal design. Bioresources 6(2):1414-1427

Zhang B, Shahbaz A, Wang L, Whitmore A, Riddick BA (2012) Fermentation of glucose and xylose in cattail processed by different pretreatment technologies. Bioresources 7(3):2848-2859

Zheng J, Rehmann L (2014) Extrusion pretreatment of lignocellulosic biomass: a review. Int J Mol Sci 15:18967-18984

Zheng Y, Zhao J, Fuqing X, Li Y (2014) Pretreatment of lignocellulosic biomass for enhanced biogas production. Prog Energy Combust Sci 42:35-53 